\title{
Traumatic rosette cataract
}

\author{
Rohan Bir Singh, ${ }^{1,2}$ Sahil Thakur, ${ }^{2}$ Parul Ichhpujani ${ }^{2}$
}

'Department of Ophthalmology, Harvard Medical School, Boston, Massachusetts, USA ${ }^{2}$ Department of Ophthalmology, Government Medical College and Hospital, Chandigarh, Punjab, India

\section{Correspondence to} Dr Rohan Bir Singh, dr.rohandhaliwal@gmail.com and Dr Parul Ichhpujani, parul77@rediffmail.com, itsdrparul@gmail.com

Accepted 26 October 2018

\section{DESCRIPTION}

A 36-year-old man presented to our ophthalmology clinic with redness, pain and progressively diminishing vision in the left eye for 2 days. He had sustained a blunt trauma from a fist punch to the left side of his face, 6-7 hours before the appearance of first symptoms. His best corrected visual acuity was 20/50 in the left eye and 20/20 in the right eye. The intraocular pressure was $15 \mathrm{~mm} \mathrm{Hg}$ in both eyes. The slit lamp biomicroscopy of the left eye showed white axial opacities in the form of five distinct quadrangular 'petals', giving it a characteristic rosette pattern (figure 1). The posterior segment examination, performed after dilation, was essentially normal in both eyes (figure 2 ). The patient underwent cataract extraction surgery with intraocular lens implantation (figure 3). One week after the surgery, the patient's distance and near visual acuity were recorded to be $20 / 20$ and N6 with $+2 \mathrm{D}$, respectively.

The cataracts presenting with petaloid/ rosette-shaped opacifications are typically seen in patients who have sustained blunt or penetrating physical trauma to the eye, and rarely due to electric shock, exposure to infrared energy or ionising radiation. The force of the blunt trauma may result in coup, contrecoup injury or axial expansion of the lens. ${ }^{1}$ The coup ocular injury is a result of direct impact, and results in formation of a Vossius ring as a consequence of compression of the pigmented posterior iris epithelial cells against the anterior lens

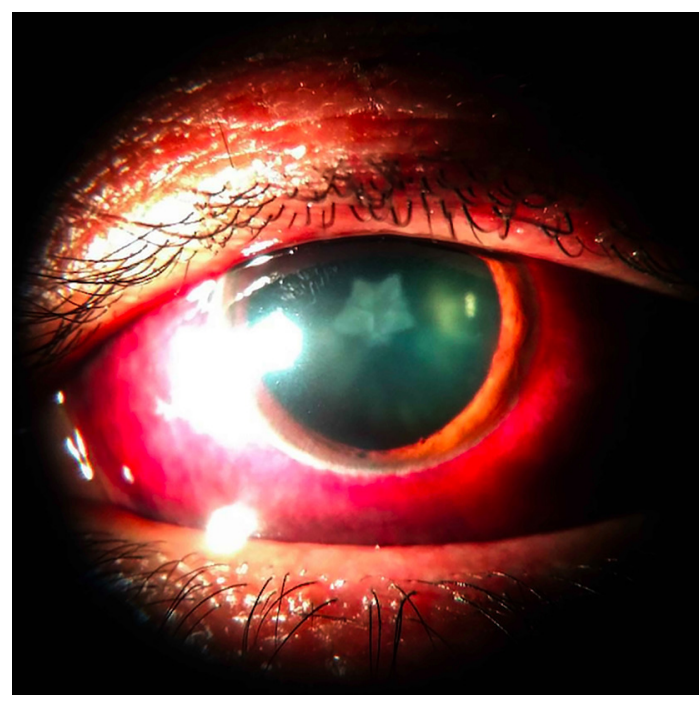

Figure 1 The patient's slit lamp examination showed white axial quadrangular petal-shaped opacities arranged in a floral pattern in the left eye.

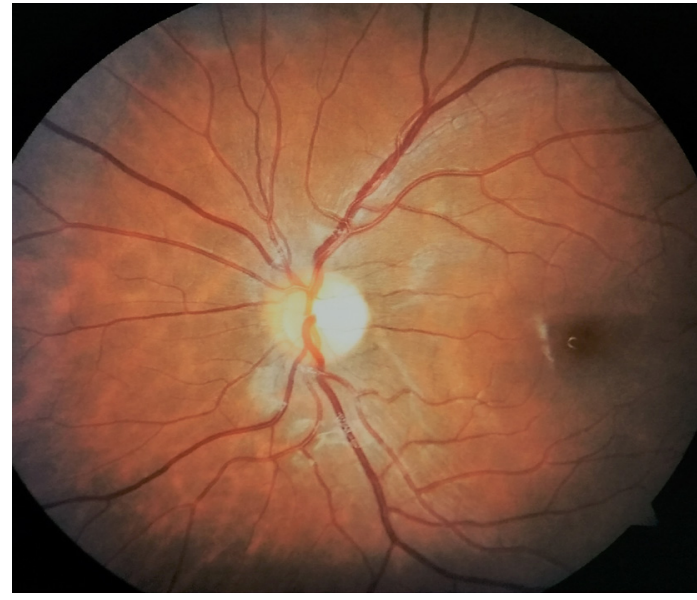

Figure 2 The posterior segment examination, performed after dilation, was essentially normal in the left eye.

capsule. ${ }^{2}$ The contrecoup injury generates shock waves along the line of impact of trauma, and may result in posterior cortical opacification in rosette or stellate shape as seen in our patient. ${ }^{3}$ The axial expansion causes rapid anterioposterior expansion and may disrupt the lens capsule and/or zonules. These opacifications may appear immediately after, or even up to few months after the trauma is inflicted. The opacities formed due to trauma may be stable or progressive. A thorough ocular examination in such cases is essential to ensure other ocular comorbidities, that is, rupture of globe, subluxation of lenses, choroidal detachment, angle recession glaucoma, retinal detachment, traumatic optic

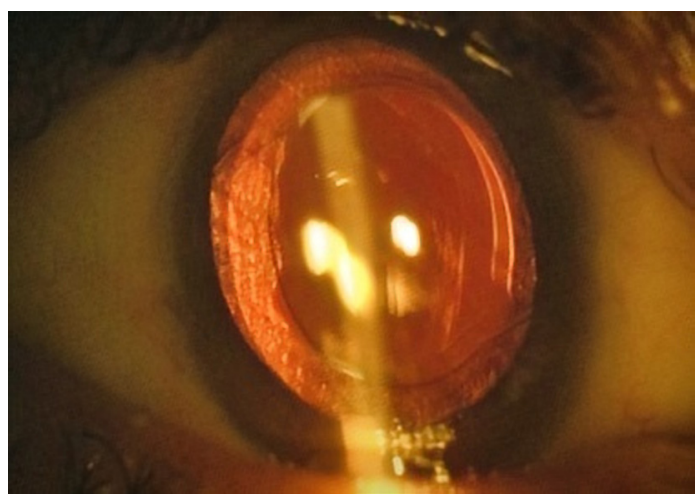

Figure 3 The patient underwent cataract extraction surgery with intraocular lens implantation in the left eye. One week after the surgery, the patient's distance and near visual acuity were recorded to be $20 / 20$ and N6 with $+2 D$, respectively. 
neuropathy, retrobulbar haemorrhage, and so on, are not missed.

\section{Learning points}

- Atypical stellate/rosette-shaped cataracts may be formed due to exposure to radiation or physical trauma.

- High clinical suspicion and a thorough ocular examination are essential to rule out any ocular comorbidity in patients presenting with traumatic cataract.

Contributors RBS and ST authored the manuscript. PI managed the patient, provided the images and edited the manuscript.
Funding The authors have not declared a specific grant for this research from any funding agency in the public, commercial or not-for-profit sectors.

Competing interests None declared.

Patient consent Obtained.

Provenance and peer review Not commissioned; externally peer reviewed.

\section{REFERENCES}

1 Tabatabaei A, Kiarudi MY, Ghassemi F, et al. Evaluation of posterior lens capsule by $20-\mathrm{MHz}$ ultrasound probe in traumatic cataract. Am J Ophthalmol 2012;153:51-4.

2 Zentmayer W. The pathogenesis of vossius ring cataract. Am J Ophthalmol 1924;7:676-7.

3 Shah MA, Shah SM, Shah SB, et al. Morphology of traumatic cataract: does it play a role in final visual outcome? BMJ Open 2011;1:e000060.

Copyright 2018 BMJ Publishing Group. All rights reserved. For permission to reuse any of this content visit https://www.bmj.com/company/products-services/rights-and-licensing/permissions/

BMJ Case Report Fellows may re-use this article for personal use and teaching without any further permission.

Become a Fellow of BMJ Case Reports today and you can:

- Submit as many cases as you like

- Enjoy fast sympathetic peer review and rapid publication of accepted articles

- Access all the published articles

- Re-use any of the published material for personal use and teaching without further permission

For information on Institutional Fellowships contact consortiasales@bmjgroup.com

Visit casereports.bmj.com for more articles like this and to become a Fellow 